\title{
Evaluasi Kebijakan Spasial Perlindungan Lahan Pertanian Pangan Berkelanjutan di Kecamatan Kaliwungu Kabupaten Kendal
}

\section{Evaluation Of Spatial Policy For Sustainable Food Protection In Kaliwungu District Kendal District}

\author{
Widya Kusuma Harniawati1), Kismartini') \& Hartuti P2) \\ 1)Fakultas Ilmu Sosial dan Ilmu Politik, Universitas Diponegoro, Indonesia \\ 2)Fakultas Ilmu Lingkungan, Universitas Diponegoro, Indonesia
}

Diterima: 17 Agustus 2020; Disetujui: 14 Desember 2020; Dipublish: 31 Januari 2021 \begin{abstract}
Abstrak
Artikel ini bertujuan mengevaluasi kebijakan perlindungan lahan pertanian pangan berkelanjutan di Kecamatan Kaliwungu, Kabupaten Kendal. Pemilihan Kecamatan Kaliwungu sebagai lokasi penelitian, karena tingkat alih fungsi lahan pertanian ke non pertanian yang paling tinggi. Metode penelitian yang digunakan deskriptif kualitatif. Teknik analisis data yang digunkana yaitu hasil analisis SIG (Sistem Informasi Geografi) untuk melihat peta penggunaan tanah dari tahun 2011-2017. Kemudian akan dianalisis dan mengevaluasi kebijakan perlindungan lahan pertanian pangan berkelanjutan, dengan data observasi, dan dokumentasi . Hasil penelitian menunjukkan bahwa terdapat perubahan penggunaan lahan Kecamatan Kaliwungu dari tahun 2011-2017 sebesar 166,06 Ha. Evaluasi kebijakan perlindungan lahan pertanian pangan berkelanjutan di Kecamatan Kaliwungu, menunjukkan bahwa terdapat perbedaan persebaran penetapan lahan pertanian pangan berkelanjutan antara Perda Kabupaten Kendal Nomor 13 Tahun 2013 dan Perda Kabupaten Kendal Nomor 20 Tahun 2011, sedangkan kegiatan pengembangan, penelitian, pemanfaatan, pembinaan, pengendalian, alih fungsi, sistem informasi, perlindungan dan pemberdayaan petani, pembiayaan, peran serta masyarakat dan pengawasan dalam rangka perlindungan lahan pertanian pangan berkelanjutan belum terlaksana. Peneliti merekomendasikan agar sosialisasi, kerjasama antar instansi dan implementasi kegiatan perlindungan lahan pertanian pangan berkelanjutan segera dilaksanakan dengan baik, cermat dan tepat demi tercapainya ketahanan pangan di Kecamatan Kaliwungu pada khususnya dan Indonesia pada umumnya.
\end{abstract}

Kata Kunci: Lahan Pertanian, Lahan Pertanian Pangan Berkelanjutan, Perlindungan Lahan Pertanian Pangan Berkelanjutan

\section{Abstract}

This article aims to evaluate the policy of protecting sustainable food agriculture in Kaliwungu District, Kendal Regency. Kaliwungu Subdistrict was chosen as the research location, because the rate of conversion of agricultural land to non-agricultural functions was the highest. The research method used is descriptive qualitative. The data analysis technique used is the results of the GIS (Geographic Information System) analysis to view the land use map from 2011-2017, which will then be analyzed and evaluated the policy of protecting sustainable agricultural land for food, with observational data and documentation. The results showed that there was a change in land use in Kaliwungu District from 2011-2017 amounting to $166.06 \mathrm{Ha}$. Evaluation of policies for the protection of sustainable food agriculture land in Kaliwungu District, shows that there is a difference in the distribution of the designation of sustainable food agriculture between the Kendal Regency Regional Regulation Number 13 of 2013 and the Kendal Regency Regional Regulation Number 20 of 2011, while the development, research, utilization, guidance, control, transfer of functions, information systems, protection and empowerment of farmers, financing, community participation and supervision in the framework of protecting sustainable agricultural food land have not been implemented. Researchers recommend that the socialization, cooperation between agencies and the implementation of activities to protect sustainable agricultural land should be carried out quickly, carefully and precisely in order to achieve food security in Kaliwungu District in particular and Indonesia in general.

Keywords: Agricultural Land, Sustainable Food Agricultural Land, Protection Of Sustainable Food Agricultural Land

How to Cite: Harniawati, W.K. Kismartini. \& Purnaweni, H. (2021). Evaluasi Kebijakan Spasial Perlindungan Lahan Pertanian Pangan Berkelanjutan Di Kecamatan Kaliwungu Kabupaten Kendal. PERSPEKTIF, 10 (1): 106-111

*Corresponding author:

E-mail: widvaharniawati@gmail.com 


\section{PENDAHULUAN}

Kebutuhan dasar manusia yang penting adalah pangan. Isu mengenai ketahanan pangan (food security) dan keamanan pangan (food safety) selalu menjadi perhatian dunia. Permintaan kebutuhan pangan meningkat sejalan dengan bertambahnya populasi penduduk di seluruh dunia. Badan Pusat Statistik Indonesia (2017) mencatat bahwa penduduk terbanyak berada di Pulau Jawa sebesar 146.673 juta orang dan laju pertumbuhan penduduk dari tahun 2000-2010 dibandingkan dengan tahun 2010-2016 yang meningkat tajam (naik sebesar 0,42\%) berada pada Provinsi Jawa Tengah.

Keberhasilan kedaulatan pangan erat kaitannya dengan ketersediaan lahan pertanian. Lahan termasuk sumber daya alam yang jumlahnya sulit bertambah, tetapi kebutuhan akan lahan semakin meningkat (Gesthi, Edi dan Subejo, 2016). Menurut Meirina (2012) tersedianya lahan pertanian merupakan syarat mutlak dalam terpenuhinya swasembada pangan sekaligus menguatkan ketahanan pangan nasional. Di sisi lain, kebutuhan lahan untuk kegiatan non pertanian juga meningkat sejalan pertumbuhan penduduk. Sementara lahan yang tersedia tetap, sehingga memicu alih fungsi (konversi) lahan, penyerobotan lahan, saling klaim lahan bahkan sengketa lahan. Temuan (Rosyadi dan Purnomo, 2012) di desa tertingal Weru Sukoharjo yang melihat tingkat ketahanan pangan menemukan, peningkatan produksi belum mampu mengimbangi pertumbuhan konsumsi beras yang tumbuh lebih tinggi dari pertumbuhan produksi padi. Artinya bahwa ketersediaan pangan, ketahanan pangan di daerah penelitian masih sangat rendah.

Alih fungsi lahan telah menjadi masalah besar setiap daerah di Indonesia, penelitian Kusumastuti, M. Kolopaking, \& Barus, (2018), di Kabupaten Pandeglang meyebut faktor utama alih fungsi lahan disebapkan faktor ekonomi luasnya penguasaan lahan dan B/C rasio usaha tani padi dan Faktor kebijakan yang diujur dari luas jalan. Faktor lain adalah harga jual tanah yang tinggi ( Mahardika \& Muta'ali, 2018). Alih fungsi lahan berdampak pada pendapatan petani yang berkurang karena lahan sawah menyusut. Kentrampilan petani yang minim dan tingkat pendidikan yang rendah menjadi penyebap pendapatan petani terus menurun, karena tidak bisa mengakses pekerjaan formal (Dewi \& Rudiarto, 2013). Ahlih fungsi lahan harus sebanding dengan pertumbuhan lahan baru seperti tumuan Purwanto, Fajarningsih, \& Ani, (2010), sehingga tidak mempengaruhi kebutuhan pangan seperti yang terjadi di Kabupaten Klaten. Alih fungsi lahan sawah dapat berdampak negatif terhadap ketersediaan pangan penduduk. Terjadinya alih fungsi lahan menyebabkan timbulnya kehilangan hasil produksi padi dan beras yang dapat dicapai (Prasada \& Rosa, 2018). Terlebih sulitnya menciptakan lahan sawah baru seperti yang terjadi di Kabupaten Kating Provinsi Kalimantan Timur yang disebapkan kelembagaan dan infrastrukur, serta aspek ekologi (Mustapa, Purnamadewi, \& Dharmawan, 2019).

Alih fungsi lahan pertanian telah menjadi masalah publik, Menurut John M. Pfiffner dan Robert V. Presthus (1960)dibutuhkan administrasi publik yang merupakan pelaksanaan kebijakan negara oleh badan perwakilan politik (Natalia, 2014). Oleh karena itu, pemerintah menerbitkan kebijakan spasial/kebijakan penataan ruang yaitu Undang-undang Nomor 26 Tahun 2007 tentang Penataan Ruang dan Undang Undang Nomor 41 Tahun 2009 tentang Perlindungan Lahan Pertanian Pangan Berkelanjutan. Menindaklanjuti penerbitan kebijakan nasional, Provinsi Jawa Tengah juga menerbitkan Peraturan Daerah Provinsi Jawa Tengah Nomor 6 Tahun 2010 tentang Rencana Tata Ruang Wilayah Provinsi Jawa Tengah Tahun 2009-2029 dan Peraturan Daerah Provinsi Jawa Tengah Nomor 2 Tahun 2013 tentang Perlindungan Lahan Pertanian Pangan Berkelanjutan Provinsi Jawa Tengah. Kabupaten Kendal selanjutnya menetapkan Peraturan Daerah Kabupaten Kendal Nomor 13 Tahun 2013 tentang Perlindungan Lahan Pertanian Pangan Berkelanjutan di Kabupaten Kendal sebagai Peraturan Daerah yang pertama kali terbit setelah adanya penetapan Peraturan Daerah Provinsi Jawa Tengah Nomor 2 Tahun 2013.

Lahan pertanian paling rawan terjadi alih fungsi yang disebapkan kepadatan penduduk, daerah pesawahan lokasinya berdekatan dengan daerah perkotaan, pola pembangunan dan Pembangunan prasarana pemukiman, kawasan industri, dan lain-lain (Putra, 2015). Letak kabupaten Kendal yang dekat dengan 
kota-kota besar, berjada dijalur lintas provinsi dan terdapat kawasan industri sangat rawan terjadi alih fungsi lahan. Hal tersebut sejalan penjelasan Kustiawan (1997) dalam Massardy (2009) alih fungsi lahan sawah banyak terjadi di Pulau Jawa yaitu di wilayah Pantura, yang dialih fungsi menjadi perumahan, industri, dan prasarana (I Ketut, 2014). Meskipun Pulau Jawa terus mengalami penyusutan lahan, namun memiliki potensi menyediakan lahan sawah baru seluas $8.292 \mathrm{Km}^{2}$ yang tersebar di 50 Kabupaten (Kusumawardhani, Syetiawan, Rah, \& Ristiantri, 2020). Potensi tersebut tidak sebanding dengan alih fungsi lahan yang terus terjadi seiring meningkatnya penduduk dan industri. Temuan Purwaningsih, Istiqomah, \& Sutomo, (2015), tidak adanya alih fungsi lahan berdampak baik terhadap ketahanan pangan keluarga dan mendapatkan akses pangan baik. artinya pemerintah harus menjadikan dasar untuk mencegah alih fungsi lahan.

Dalam rangka mengetahui tingginya perubahan pengunaan lahan di Kabupaten Kendal, diperoleh data dari Kantor Pertanahan Kabupaten Kendal. Berikut adalah perubahan penggunaan lahan di Kabupaten Kendal dari tahun 2015-2017 berdasarkan data permohonan PTP (Pertimbangan Teknis Pertanahan) yang merupakan salah syarat perizinan dalam rangka perubahan penggunaan lahan.

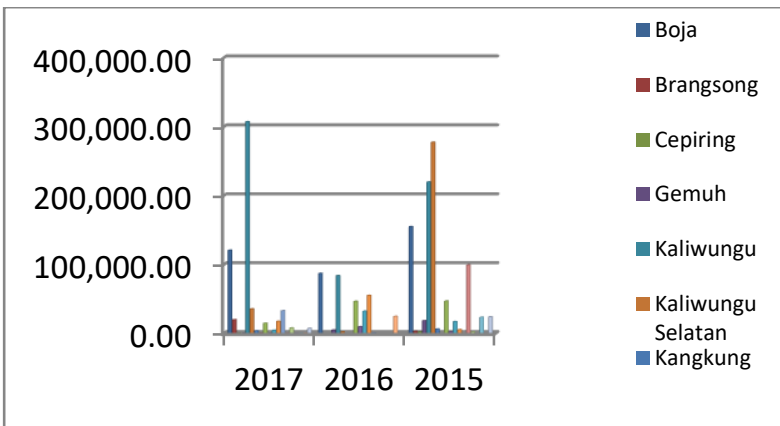

Diagram 1. Data Perubahan Penggunaan Lahan dari Pertanian ke non Pertanian Kabupaten Kendal Berdasarkan Permohonan PTP Kantor Pertanahan Kabupaten Kendal Tahun 2015-2017

Sumber : Data Pemohon PTP Kantor Pertanahan Kabupaten Kendal Tahun 2015-2017

Mengamati data di atas, penulis memutuskan untuk melaksanakan penelitian di Kecamatan Kaliwungu mengingat tingginya laju perubahan penggunaan lahan dari pertanian ke non pertanian dari tahun 2015-
2017 jika dibandingkan dengan kecamatan lainnya.

Melihat kondisi tersebut, apakah kebijakan terkait penataan ruang dan perlindungan lahan pertanian pangan berkelanjutan mampu menahan tingginya laju perubahan penggunaan lahan dari lahan pertanian menjadi lahan non pertanian. Maka perlu kiranya dilaksanakan penelitian tentang evaluasi kebijakan spasial perlindungan lahan pertanian pangan berkelanjutan di Kecamatan Kaliwungu Kabupaten Kendal Provinsi Jawa Tengah.

\section{METODE PENELITIAN}

Peneliti ini menggunakan metode peneltian deskriptif kualitatif. Lokasi penelitian di Kecamatan Kaliwungu, Kabupaten Kendal, Provinsi Jawa Tengah. Pemilihan Kecamatan Kaliwungu sebagai lokasi karena kecamatan di Kabupaten Kendal dengan tingkat alih fungsi lahan pertanian ke non pertanian yang paling tinggi dibandingkan dengan kecamatan lain di Kabupaten Kendal selama tahun 2015-2017. Penelitian ini diawali dengan membandingkan peta penggunaan tanah tahun 2011 dan 2017 dengan analisis SIG (Sistem Informasi Geografi) dilakukan dengan teknik overlay (tumpang susun) 2) peta dengan software ArcGis 10.1, kemudian dianalisis perubahan penggunan tanahnya dengan menunjukan perubahan.

Penelitian ini juga menganalisis evaluasi kebijakan perlindungan lahan pertanian pangan berkelanjutan di Kecamatan Kaliwungu. Teknik pengumpulan data menggunakan dokumentasi, dan observasi.

\section{HASIL DAN PEMBAHASAN}

\section{Alih Fungsi Lahan dari Pertanian ke Non Pertanian di Kecamatan Kaliwungu, Kabupaten Kendal}

Analisis perubahan penggunaan tanah berfungsi untuk mengetahui luas dan lokasi perubahan penggunaan tanah, maupun kecenderungan perkembangan aktifitas masyarakat suatu wilayah dalam kurun waktu tertentu. Analisis perubahan penggunaan tanah dilakukan dengan overlay (tumpang-tindih) Peta Penggunaan Tanah Tahun 2011 dan Peta Penggunaan Tanah Tahun 2017 sehingga dihasilkan Perubahan Penggunaan Tanah. Langkah-langkah analisis perubahan penggunaan tanah dapat dilihat pada Diagram 2 berikut. 
Widya Kusuma Harniawati, Kismartini \& Hartuti P, Evaluasi Kebijakan Spasial Perlindungan

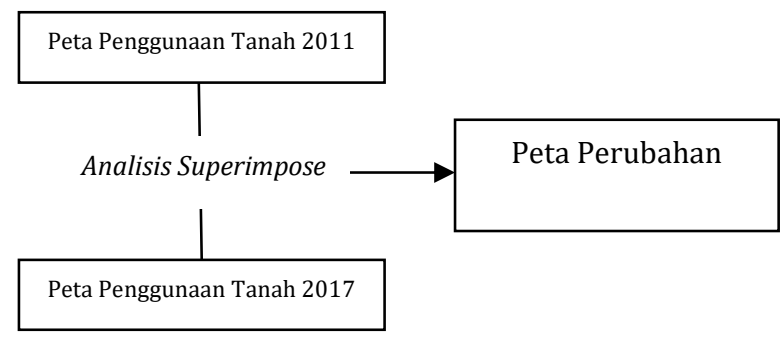

Diagram 2. Analisis Perubahan Penggunaan Tanah

Penggunaan tanah Kecamatan Kaliwungu, Kabupaten Kendal Tahun 2011 dapat dilihat pada Tabel 1 Berikut ini.

Tabel 1. Penggunaan Tanah Kecamatan Kaliwungu, Kabupaten Kendal Tahun 2011

\begin{tabular}{ccrr}
\hline No & $\begin{array}{c}\text { Penggunaan } \\
\text { Tanah }\end{array}$ & $\begin{array}{r}\text { Luas } \\
\text { (Ha) }\end{array}$ & $\begin{array}{r}\text { \% Luas } \\
\text { Wilayah }\end{array}$ \\
\hline $\mathbf{1}$ & Hutan & 370,02 & 8,31 \\
\hline $\mathbf{2}$ & Industri & 205,07 & 4,60 \\
\hline $\mathbf{3}$ & Kampung & 481,28 & 10,80 \\
\hline $\mathbf{4}$ & Kebun Campur & 27,61 & 0,62 \\
\hline $\mathbf{5}$ & Kuburan & 7,62 & 0,17 \\
\hline $\mathbf{6}$ & Lapangan & 4,57 & 0,10 \\
\hline $\mathbf{7}$ & Perumahan & 8,91 & 0,20 \\
\hline $\mathbf{8}$ & Sawah 2x Padi & $1.292,56$ & 29,02 \\
\hline $\mathbf{9}$ & Sungai & 29,32 & 0,66 \\
\hline $\mathbf{1 0}$ & Tambak & $1.652,56$ & 37,10 \\
\hline $\mathbf{1 1}$ & Tanah terbuka & 8,81 & 0,20 \\
& sementara & & 8,22 \\
\hline $\mathbf{1 2}$ & Tegalan & 366,38 & 100 \\
\hline & Jumlah & $4.454,71$ &
\end{tabular}

Sumber : Neraca Penatagunaan Tanah Kabupaten Kendal Tahun 2017 dan analisis penulis

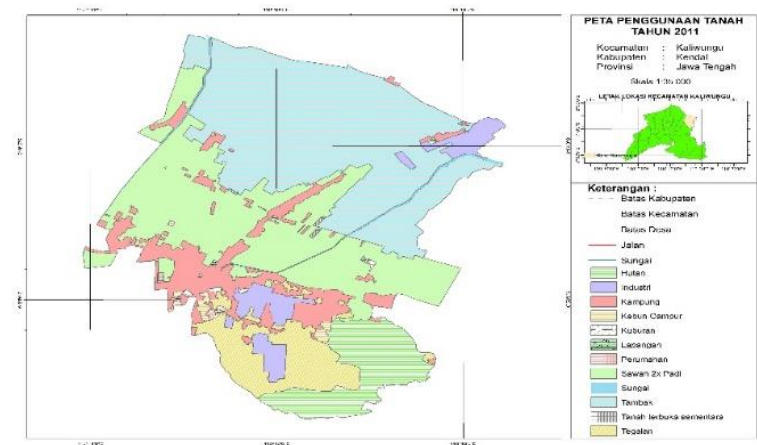

Gambar 1. Peta Penggunaan Tanah Kecamatan

Kaliwungu, Kabupate Kendal Tahun 2011

Sumber : Neraca Penatagunaan Tanah Kabupaten

Kendal Tahun 2017 dan analisis penulis

Untuk penggunaan tanah Kecamatan Kaliwungu, Kabupaten Kendal Tahun 2017 dapat dilihat pada Tabel 2 dan Gambar 2.
Tabel 2. Penggunaan Tanah Kecamatan Kaliwungu, Kabupaten Kendal Tahun 2017

\begin{tabular}{ccrr}
\hline $\begin{array}{c}\text { N } \\
\mathbf{0}\end{array}$ & $\begin{array}{c}\text { Penggunaan } \\
\text { Tanah }\end{array}$ & $\begin{array}{c}\text { Luas } \\
\text { (Ha) }\end{array}$ & $\begin{array}{c}\text { \% Luas } \\
\text { Wilayah }\end{array}$ \\
\hline $\mathbf{1}$ & Hutan & 370,02 & 8,31 \\
\hline $\mathbf{2}$ & Industri & 254,06 & 5,70 \\
\hline $\mathbf{3}$ & Kampung & 499,56 & 11,21 \\
\hline $\mathbf{4}$ & Kebun Campur & 27,61 & 0,62 \\
\hline $\mathbf{5}$ & Kuburan & 7,62 & 0,17 \\
\hline $\mathbf{6}$ & Lapangan & 4,57 & 0,10 \\
\hline $\mathbf{7}$ & Perumahan & 41,43 & 0,93 \\
\hline $\mathbf{8}$ & Sawah 2x Padi & $1.199,81$ & 26,93 \\
\hline $\mathbf{9}$ & Sungai & 29,32 & 0,66 \\
\hline $\mathbf{1 0}$ & Tambak & $1.588,32$ & 35,65 \\
\hline $\mathbf{1 1}$ & Tanah terbuka & 71,05 & 1,59 \\
& sementara & & \\
\hline $\mathbf{1 2}$ & Tegalan & 361,34 & 8,11 \\
\hline & Jumlah & $\mathbf{4 . 4 5 4 , 7 1}$ & 100 \\
\hline
\end{tabular}

Sumber : Neraca Penatagunaan Tanah Kabupaten Kendal Tahun 2017 dan analisis penulis

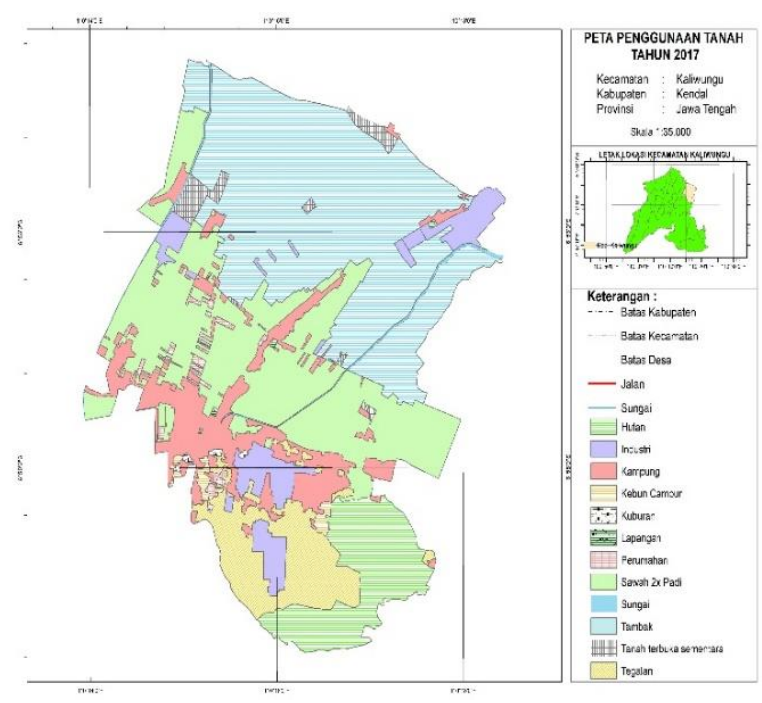

Gambar 2. Peta Penggunaan Tanah Kecamatan Kaliwungu, Kabupate Kendal Tahun 2011 Sumber : Neraca Penatagunaan Tanah Kabupaten Kendal Tahun 2017 dan analisis penulis

Mulai dari Tahun 2011 sampai dengan Tahun 2017 telah terjadi perubahan penggunaan tanah dari tanah pertanian (sawah 2x padi/tahun, dan tegalan), tambak dan tanah terbuka sementara menjadi non pertanian (perumahan, kampung, tambak, tanah terbuka sementara dan industri) seluas 166,06 Ha. Sedangkan untuk jenis penggunaan tanah lainnya, seperti hutan, kuburan, kebun campur, dan lapangan tidak mengalami perubahan luasan penggunaan tanah. Perubahan penggunaan tanah Kecamatan Kaliwungu, Kabupaten Kendal Tahun 2011-2017 dapat 
dilihat secara detail pada Tabel 3. dan Gambar

3. Berikut ini

Tabel 3. Perubahan Penggunaan Tanah Kecamatan Kaliwungu, Kabupaten Kendal Tahun 2011-2017

\begin{tabular}{|c|c|c|c|c|}
\hline \multirow[t]{2}{*}{ No } & \multicolumn{2}{|c|}{ Penggunan Tanah } & \multirow[t]{2}{*}{ Desa/Kelurahan } & \multirow{2}{*}{$\begin{array}{c}\text { Luas Perubahan } \\
\text { (Ha) }\end{array}$} \\
\hline & Tahun 2011 & Tahun 2017 & & \\
\hline \multirow[t]{25}{*}{1} & \multirow[t]{25}{*}{ Sawah 2x Padi } & \multirow[t]{3}{*}{ Industri } & \multicolumn{2}{|r|}{34,03} \\
\hline & & & Kumpulrejo & 31,06 \\
\hline & & & Wonorejo & 2,98 \\
\hline & & \multirow[t]{8}{*}{ Kampung } & & 15,60 \\
\hline & & & Karang Tengah & 1,32 \\
\hline & & & Krajan Kulon & 0,94 \\
\hline & & & Kumpulrejo & 1,13 \\
\hline & & & Mororejo & 1,23 \\
\hline & & & Sarirejo & 5,53 \\
\hline & & & Sumberejo & 1,83 \\
\hline & & & Wonorejo & 3,63 \\
\hline & & \multirow[t]{8}{*}{ Perumahan } & & 27,48 \\
\hline & & & Karang Tengah & 3,94 \\
\hline & & & Krajan Kulon & 4,31 \\
\hline & & & Kumpulrejo & 1,26 \\
\hline & & & Kutoharjo & 1,30 \\
\hline & & & Mororejo & 0,17 \\
\hline & & & Sarirejo & 14,12 \\
\hline & & & Wonorejo & 2,38 \\
\hline & & \multirow[t]{2}{*}{ Tambak } & & 0,005 \\
\hline & & & Wonorejo & 0,005 \\
\hline & & \multirow{3}{*}{$\begin{array}{l}\text { Tanah terbuka } \\
\text { sementara }\end{array}$} & & 15,63 \\
\hline & & & Kumpulrejo & 1,52 \\
\hline & & & Wonorejo & 14,11 \\
\hline & & Jumlah & & 92,75 \\
\hline \multirow[t]{10}{*}{2} & \multirow[t]{10}{*}{ Tambak } & \multirow[t]{4}{*}{ Industri } & & 13,03 \\
\hline & & & Krajan Kulon & 2,97 \\
\hline & & & Mororejo & 10,04 \\
\hline & & & Wonorejo & 0,03 \\
\hline & & \multirow[t]{2}{*}{ Kampung } & & 0,57 \\
\hline & & & Mororejo & 0,57 \\
\hline & & \multirow{3}{*}{$\begin{array}{l}\text { Tanah terbuka } \\
\text { sementara }\end{array}$} & & 50,64 \\
\hline & & & Mororejo & 2,71 \\
\hline & & & Wonorejo & 47,93 \\
\hline & & Jumlah & & 64,24 \\
\hline \multirow[t]{5}{*}{3} & \multirow{4}{*}{$\begin{array}{c}\text { Tanah } \\
\text { terbuka } \\
\text { sementara }\end{array}$} & \multirow{2}{*}{ Industri } & & 1,93 \\
\hline & & & Mororejo & 1,93 \\
\hline & & \multirow[t]{2}{*}{ Kampung } & & 2,10 \\
\hline & & & Mororejo & 2,10 \\
\hline & & Jumlah & & 4,03 \\
\hline \multirow[t]{4}{*}{4} & \multirow[t]{2}{*}{ Tegalan } & \multirow[t]{2}{*}{ Perumahan } & & 5,04 \\
\hline & & & Nolokerto & 5,04 \\
\hline & & Jumlah & & 5,04 \\
\hline & Jumlah & Keseluruhan Lua & rubahan & 166,06 \\
\hline
\end{tabular}

Sumber: Hasil analisis penulis dan Neraca Penatagunaan Tanah Kab. Kendal , 2017. 


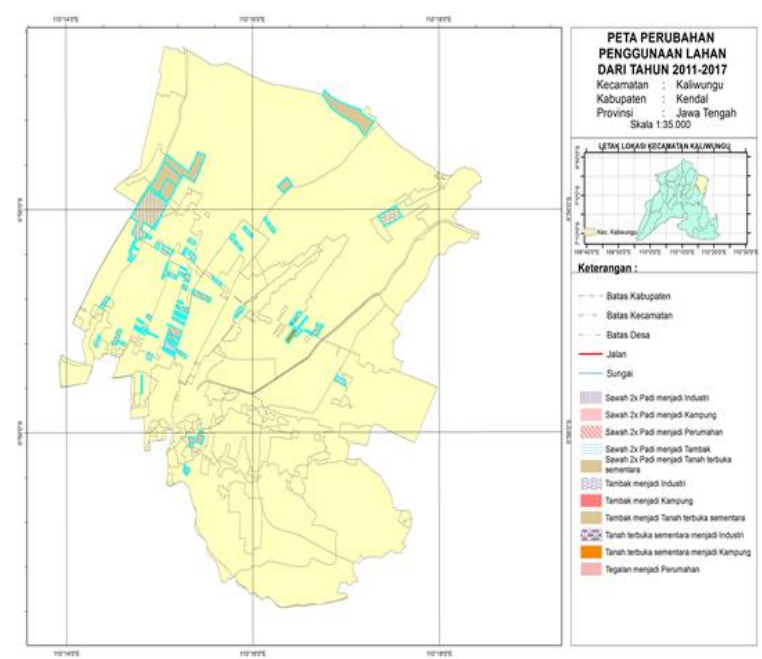

Gambar 3. Peta Perubahan Penggunaan Tanah Kecamatan Kaliwungu, Kabupaten Kendal Tahun 2011-2017

Sumber : Neraca Penatagunaan Tanah Kabupaten Kendal Tahun 2017 dan analisis penulis

Perlu upaya langkah konkirt untuk mengurangi alih fungsi lahan yang bertumpu pada masyarakat. Menurut Kaputra, (2013) tiga langkah mewujudkan strategi pengendalian alih fungsi lahan, pertama titik tumpu (entry point) strategi pengendalian adalah melalui partisipasi segenap pemangku kepentingan. Kedua, fokus analisis strategi pengendalian adalah sikap pandang pemangku kepentingan terhadap eksistensi peraturan kebijakan seperti instrumen hukum (peraturan perundang-undangan), instrumen ekonomi (insentif, disinsentif, kompensasi) dan zonasi (batasan-batasan alih fungsi lahan pertanian). Ketiga, sasaran (goal) strategi pengendalian adalah terwujudnya pengendalian alih fungsi lahan pertanian yang selaras dan berkelanjutan. Strategi tesebut sangat berguna dalam upaya mengurangi alih fungsi lahan yang terus terjadi.

\section{Evaluasi Kebijakan Perlindungan Lahan Pertanian Pangan Berkelanjutan di Kecamatan Kaliwungu, Kabupaten Kendal.}

Menurut Lestari (2009) alih fungsi lahan sebagai konversi lahan adalah perubahan fungsi sebagian atau seluruh kawasan lahan dari fungsinya semula menjadi fungsi lain yang menjadi dampak negatif (masalah) terhadap lingkungan dan potensi lahan itu sendiri (Nurpita, Wihastuti, \& Andjani, 2018). Meminimalkan potensi dampak negatif, perlu upaya untuk melindungi lahan pertanian.
Tujuan kebijakan perlindungan lahan pertanian pangan berkelanjutan di Kecamatan Kaliwungu, Kabupaten Kendal, dalam hal ini adalah Peraturan Daerah Kabupaten Kendal Nomor 13 Tahun 2013 tentang Perlindungan Lahan Pertanian Pangan Berkelanjutan di Kabupaten Kendal adalah sebagaimana yang tersebut pada Pasal 3, yaitu: melindungi kawasan dan lahan pertanian pangan secara berkelanjutan; menjamin tersedianya lahan pertanian pangan secara berkelanjutan; mewujudkan kemandirian, ketahanan dan kedaulatan pangan; melindungi kepemilikan lahan pertanian pangan milik petani; meningkatkan kemakmuran serta kesejahteraan petani dan masyarakat; meningkatkan perlindungan dan pemberdayaan petani; meningkatkan penyediaan lapangan kerja bagi kehidupan yang layak; mempertahankan keseimbangan ekologis; dan mewujudkan revitalisasi pertanian.

Tujuan perlindungan lahan pertanian pangan berkelanjutan dalam lingkup nasional tercantum dalam Pasal 3 Undang-undang Nomor 41 Tahun 2009 tentang Perlindungan Lahan Pertanian Pangan Berkelanjutan, yaitu: melindungi kawasan dan lahan pertanian pangan secara berkelanjutan; menjamin tersedianya lahan pertanian pangan secara berkelanjutan; mewujudkan kemandirian, ketahanan dan kedaulatan pangan; melindungi kepemilikan lahan pertanian pangan milik petani; meningkatkan kemakmuran serta kesejahteraan petani dan masyarakat; meningkatkan perlindungan dan pemberdayaan petani; meningkatkan penyediaan lapangan kerja bagi kehidupan yang layak; mempertahankan keseimbangan ekologis; dan mewujudkan revitalisasi pertanian.

Melihat kesamaan tujuan antara kebijakan Pemerintah Pusat dalam hal ini Undang-undang Nomor 41 Tahun 2009 tentang Perlindungan Lahan Pertanian Pangan Berkelanjutan dan kebijakan Pemerintah Daerah lokasi penelitian (Kecamatan Kaliwungu, Kabupaten Kendal) dalam hal ini Peraturan Daerah Kabupaten Kendal Nomor 13 Tahun 2013 tentang Perlindungan Lahan Pertanian Pangan Berkelanjutan di Kabupaten Kendal, maka telah terjadi sinkronisasi tujuan dari kebijakan perlindungan lahan pertanian pangan berkelanjutan untuk tingkat nasional 
dan daerah, khususnya Kabupaten Kendal, Provinsi Jawa Tengah.

Penjabaran tujuan ke dalam kriteria atau indikator pencapaian tujuan. Kriteria atau indikator pencapaian tujuan dalam kebijakan perlindungan lahan pertanian pangan berkelanjutan Kecamatan Kaliwungu, Kabupaten Kendal dapat dilihat dalam pasal 4 Peraturan Daerah Kabupaten Kendal Nomor 13 Tahun 2013 tentang Perlindungan Lahan Pertanian Pangan Berkelanjutan di Kabupaten Kendal, meliputi: Penetapan Lahan Pertanian Pangan Berkelanjutan; Berdasarkan Pasal 15 Peraturan Daerah Kabupaten Kendal Nomor 13 Tahun 2013, luas lahan pertanian pangan berkelanjutan di Daerah ditetapkan sejumlah 22.666 (dua puluh dua ribu enam ratus enam puluh enam) hektar yang tersebar di seluruh kecamatan. Untuk Kecamatan Kaliwungu ditetapkan luas lahan pertanian pangan berkelanjutan seluas 428,55 hektar.

Penetapan lahan pertanian pangan berkelanjutan pada Peraturan Daerah Kabupaten Kendal Nomor 13 Tahun 2013 seluas 428,55 Ha sama dengan penetapan luas kawasan tanaman pangan pada Perda Kabupaten Kendal Nomor 20 Tahun 2011. Namun, setelah melihat persebarannya ternyata berbeda. Untuk mengetahui perbedaan sebaran penetapan lahan pertanian pangan berkelanjutan pada Peraturan Daerah Kabupaten Kendal Nomor 13 Tahun 2013 dan Perda Kabupaten Kendal Nomor 20 Tahun 2011 dilakukan overlay (tumpang-tindih) Lampiran Peta VIII Peraturan Daerah Kabupaten Kendal Nomor 13 Tahun 2013 dan Peta Pola Ruang Perda Kabupaten Kendal Nomor 20 Tahun 2011.

Tabel 4. Hasil overlay (tumpang-tindih) Lampiran Peta VIII Peraturan Daerah Kabupaten Kendal Nomor 13 Tahun 2013 dan Peta Pola Ruang Kecamatan Kaliwungu Perda Kabupaten Kendal Nomor 20 Tahun

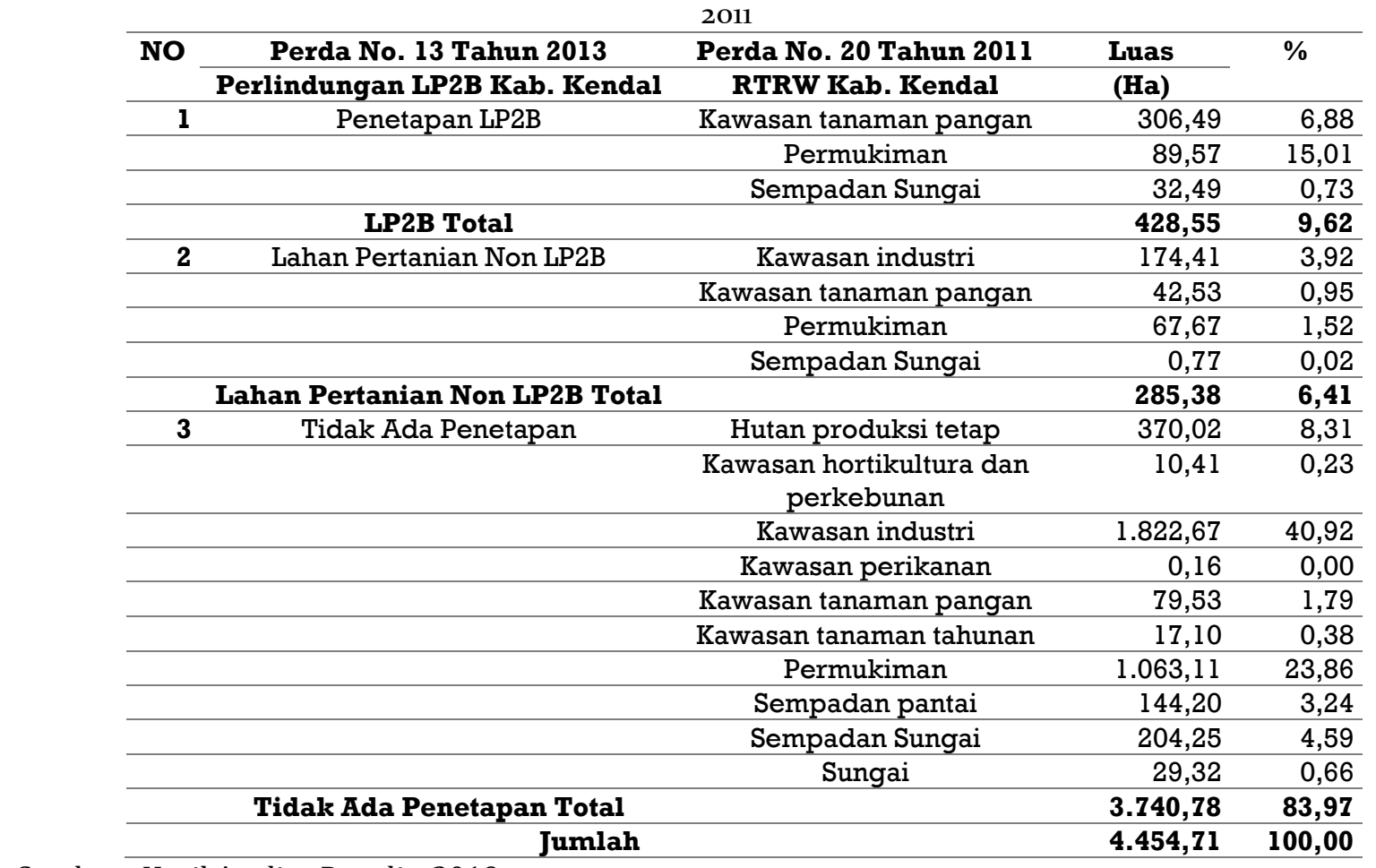

Sumber : Hasil Analisa Penulis, 2019

Persebaran penetapan LP2B pada Peraturan Daerah Kabupaten Kendal Nomor 13 Tahun 2013 menimbulkan kerancuan karena berbeda dengan Arahan Kawasan Tanaman Pangan pada Peta Pola Ruang Perda Kabupaten Kendal Nomor 20 Tahun 2011. Hal ini menimbulkan kesulitan dalam pemanfaatan dan penggunaan tanah khususnya dalam hal pemberian izin dan penanaman modal di Kecamatan Kaliwungu.

Pengembangan Lahan Pertanian Pangan Berkelanjutan; Kegiatan pengembangan Lahan Pertanian Pangan Berkelanjutan meliputi intensifikasi dan ekstensifikasi. Hasil wawancara dengan Dinas Pertanian dan Pangan Kabupaten Kendal bahwa kegiatan pengembangan yang meliputi program 
intensifikasi dan ekstensifikasi pada kawasan P2B dan LP2B di wilayah-wilayah studi secara spesifik belum dilakukan. Namun, program intensifikasi seperti yang disebutkan diatas merupakan kegiatan reguler dari Pemerintah Pusat/Dinas Pertanian/Tanaman Pangan di Kabupaten.

Penelitian Lahan Pertanian Pangan Berkelanjutan Dinas Pertanian dan Pangan Kabupaten Kendal menyatakan bahwa kegiatan penelitian belum pernah dlakukan, namun tidak menutup kemungkinan bahwa adanya penelitian terkait lahan pertanian pangan berkelanjutan yang dilakukan secara independen oleh mahasiswa.

Pemanfatan Lahan Pertanian Pangan Berkelanjutan Berdasarkan hasil survey kami di Kecamatan Kaliwungu, di Desa Kutoharjo, Desa Nolokerto, dan Desa Sarirejo petani berinisiatif untuk melaksanakan kegiatan gotong-royong bersih-bersih sungai dan irigasi untuk memperlancar aliran untuk mengaliri sawah-sawah yang mereka garap. Kegiatan gotong-royong ini dilaksanakan saat akan menanam padi dan sudah menjadi kebiasaan yang dilaksanakan secara suka rela. Dalam hal sulitnya perolehan air, petani menjadwal pengaturan air yang dijaga secara berkala oleh petani setempat agar petani memperoleh air secara adil.

Pembinaan Lahan Pertanian Pangan Berkelanjutan. Pembinaan Lahan Pertanian Pangan Berkelanjutan belum dilakukan Pemda Kabupaten Kendal, khususnya Dinas Pertanian dan Pangan Kabupaten Kendal

Pengendalian Lahan Pertanian Pangan Berkelanjutan. Pemerintah Daerah Kabupaten Kendal khususnya Dinas Pertanian dan Pangan Kabupaten Kendal belum melaksanakan pengendalian Lahan Pertanian Pangan Berkelanjutan: insentif, disinsentif, mekanisme perizinan, proteksi dan penyuluhan. Beberapa faktor belum diterapkannya aspek pengendalian ini antara lain: a) Jenis insentif (berupa keringanan pajak bumi dan bangunan, pengembangan infrastruktur pertanian, pembiayaan penelitian dan pengembangan benih dan varietas unggul, kemudahan mengakses informasi dan teknologi, penyediaan sarana dan prasarana produksi pertanian, jaminan penerbitan sertifikat bidang tanah pertanian pangan melalui pendaftaran tanah secara sporadik dan sistematik dan penghargaan petani berprestasi tinggi ) tidak menarik petani; b) Pemerintah daerah belum mampu menyediakan dana jika harus memberikan insentif kepada petani LP2B.

Alih Fungsi Lahan Pertanian Pangan Berkelanjutan; Alih fungsi Lahan Pertanian Pangan Berkelanjutan dapat dilakukan oleh Pemerintah, Pemerintah Daerah Provinsi dan/atau Pemerintah Daerah Kabupaten Kendal dalam rangka pengadaan tanah untuk kepentingan umum atau terjadi bencana. Namun pada pelaksanaanya telah terjadi banyaknya alih fungsi lahan pertanian yang ditetapkan sebagai Lahan Pertanian Pangan Berkelanjutan berdasarkan Peraturan Daerah Kabupaten Kendal Nomor 13 Tahun 2013 dan arahan kawasan tanaman pangan pada Peta Pola Ruang Rencana Tata Ruang Wilayah Kabupaten Kendal Peraturan Daerah Kabupaten Kendal Nomor 20 Tahun 2011. Alih fungsi lahan pertanian yang ditetapkan sebagai Lahan Pertanian Pangan Berkelanjutan dan arahan kawasan tanaman pangan terjadi pada penggunaan lahan sebagai sawah $2 x$ padi yang berubah menjadi: a) Industri pada arahan kawasan tanaman pangan seluas 0,7308 $\mathrm{Ha}$ tersebar di wilayah Desa Wonorejo; b) Kampung pada arahan kawasan tanaman pangan seluas 3,9046 Ha tersebar di wilayah Desa Kumpulrejo, Desa Mororejo, Desa Sarirejo, dan Desa Sumberejo; c) Kampung pada penetapan Lahan Pertanian Pangan Berkelanjutan seluas 0,2531 Ha tersebar di wilayah Desa Karang Tengah, Desa Wonorejo, dan Desa Sarirejo; d) Perumahan pada arahan kawasan tanaman pangan seluas $1,5227 \mathrm{Ha}$ tersebar di wilayah Desa Karang Tengah, Desa Kumpulrejo, dan Desa Sarirejo; e) Perumahan pada penetapan Lahan Pertanian Pangan Berkelanjutan seluas 0,4870 Ha tersebar di Desa Karang Tengah, Desa Kutoharjo, dan Desa Sarirejo. Dari uraian tersebut, dari Tahun 2011 sampai dengan Tahun 2017 telah terjadi perubahan penggunaan tanah dari tanah pertanian (sawah $2 x$ padi/tahun), menjadi non pertanian (perumahan, kampung, dan industri) seluas 6,8776 Ha. Perubahan penggunaan lahan pertanian yang ditetapkan sebagai Lahan Pertanian Pangan Berkelanjutan dan arahan kawasan tanaman pangan Kecamatan Kaliwungu, Kabupaten Kendal Tahun 20112017 dapat dilihat secara detail berikut. 
Tabel 5 Perubahan Penggunaan Tanah pada Tahun 2011-2017 dalam Arahan Kawasan Tanaman Pangan

\begin{tabular}{|c|c|c|c|}
\hline No & Desa & $\begin{array}{c}\text { Perubahan Penggunan Tanah dalam Arahan Kawasan } \\
\text { Tanaman Pangan dan Penetapan LP2B }\end{array}$ & Luas (Ha) \\
\hline \multirow[t]{4}{*}{1} & \multirow[t]{3}{*}{ Karang Tengah } & Sawah 2x Padi menjadi Kampung dalam penetapan LP2B & 0,0024 \\
\hline & & $\begin{array}{l}\text { Sawah 2x Padi menjadi Perumahan dalam arahan Kawasan } \\
\text { tanaman pangan }\end{array}$ & 0,0038 \\
\hline & & Sawah 2x Padi menjadi Perumahan dalam penetapan LP2B & 0,2227 \\
\hline & Karang Tengah Total & & 0,2289 \\
\hline \multirow[t]{3}{*}{2} & \multirow[t]{2}{*}{ Kumpulrejo } & $\begin{array}{l}\text { Sawah 2x Padi menjadi Kampung dalam arahan Kawasan } \\
\text { tanaman pangan }\end{array}$ & 1,1252 \\
\hline & & $\begin{array}{l}\text { Sawah 2x Padi menjadi Perumahan dalam arahan Kawasan } \\
\text { tanaman pangan }\end{array}$ & 1,2515 \\
\hline & Kumpulrejo Total & & 2,3767 \\
\hline \multirow[t]{2}{*}{3} & Kutoharjo & Sawah 2x Padi menjadi Perumahan dalam penetapan LP2B & 0,0206 \\
\hline & Kutoharjo Total & & 0,0206 \\
\hline \multirow[t]{2}{*}{4} & Mororejo & $\begin{array}{l}\text { Sawah 2x Padi menjadi Kampung dalam arahan Kawasan } \\
\text { tanaman pangan }\end{array}$ & 0,4417 \\
\hline & Mororejo Total & & 0,4417 \\
\hline \multirow[t]{5}{*}{5} & \multirow[t]{4}{*}{ Sarirejo } & $\begin{array}{l}\text { Sawah 2x Padi menjadi Kampung dalam arahan Kawasan } \\
\text { tanaman pangan }\end{array}$ & 0,5080 \\
\hline & & Sawah 2x Padi menjadi Kampung dalam penetapan LP2B & 0,1454 \\
\hline & & $\begin{array}{l}\text { Sawah 2x Padi menjadi Perumahan dalam arahan Kawasan } \\
\text { tanaman pangan }\end{array}$ & 0,2673 \\
\hline & & Sawah 2x Padi menjadi Perumahan dalam penetapan LP2B & 0,2437 \\
\hline & Sarirejo Total & & 1,1645 \\
\hline \multirow[t]{2}{*}{6} & Sumberejo & $\begin{array}{l}\text { Sawah 2x Padi menjadi Kampung dalam arahan Kawasan } \\
\text { tanaman pangan }\end{array}$ & 1,8297 \\
\hline & Sumberejo Total & & 1,8297 \\
\hline \multirow[t]{4}{*}{7} & \multirow[t]{2}{*}{ Wonorejo } & $\begin{array}{l}\text { Sawah 2x Padi menjadi Industri dalam arahan Kawasan } \\
\text { tanaman pangan }\end{array}$ & 0,7308 \\
\hline & & Sawah 2x Padi menjadi Kampung dalam penetapan LP2B & 0,1052 \\
\hline & Wonorejo Total & & 0,8361 \\
\hline & & Jumlah keseluruhan & 6,8776 \\
\hline
\end{tabular}

Sumber : Analisa Penulis, 2019

Sistem Informasi; Sistem informasi data Lahan Pertanian Pangan Berkelanjutan di Kabupaten Kendal khususnya Kecamatan Kaliwungu menurut hasil wawancara dengan pihak Bappeda Kabupaten Kendal dan Dinas Pertanian dan Pangan Kabupaten Kendal belum pernah dilaksanakan dan masih belum diketahui format sistem informasi data Lahan Pertanian Pangan Berkelanjutan. Sebaiknya, sistem informasi tersebut digabung dalam BKPRD (Badan Koordinasi Penataan Ruang Daerah) yang ada di Bappeda karena wadah tersebut merupakan badan koordinasi untuk penanganan tata ruang wilayah dan untuk terciptanya kesatuan data yang komprehensif.

Perlindungan dan Pemberdayaan Petani; Dalam hal memberdayakan petani untuk kegiatan lahan pertanian pangan berkelanjutan belum dilakukan karena belum jelasnya penetapan lahan pertanian pangan berkelanjutan di Kabupaten Kendal, khususnya Kecamatan Kaliwungu. Akan tetapi, jika kegiatan perlindungan dan pemberdayaan petani dalam konteks di luar LP2B, maka pemerintah telah melakukan upaya perlindungan dan pemberdayaan melalui berbagai program dan kegiatan. Beberapa hal perlindungan dan pemberdayaan petani yang dilakukan pemerintah di luar konteks LP2B adalah sebagai berikut: a) Jaminan harga komoditas pangan pokok. Walaupun tidak seluruh harga komoditas mendapat jaminan dari pemerintah, namun untuk penentuan harga dasar gabah, pemerintah ikut campur 
tangan karena beras merupakan komoditas yang sangat strategis yang memiliki nilai politis yang tinggi; b) Jaminan memperoleh sarana dan prasarana produksi. Sejak jaman orde baru sampai saat ini, pemerintah terus berupaya agar para petani mendapatkan prasarana dan sarana produksi pertanian, seperti irigasi dan bantuan alat dan mesin pertanian. c) Jaminan pemasaran hasil pertanian pangan pokok. Pemerintah melalui Badan Urusan Logistik (Bulog) memberikan jaminan pemasaran padi dengan harga dasar yang telah ditetapkan oleh pemerintah. d) Jaminan penguatan hasil pertanian pangan dalam negeri. Salah satu program penguatan yang dilakukan pemerintah untuk pertanian tanaman padi adalah bantuan alat perontok padi agar jumlah gabah yang hilang dapat diminimalisir. e) Jaminan ganti rugi akibat gagal panen. Pemerintah telah melaksanakan ganti rugi kepada petani yang gagal panen akibat serangan hama ataupun bencana alam melalui pemberian bantuan puso atau sekarang ini diinisiasi melalui program asuransi pertanian; f) Jaminan perlindungan sosial yang menjadi bagian dari sistem jaminan sosial. Dalam konteks jaminan sosial, kebanyakan petani belum mampu mengakses sistem jaminan sosial yang diluncurkan pemerintah karena kurangnya informasi kepada petani.

Pembiayaan perlindungan lahan pertanian pangan berkelanjutan. Dalam pelaksanaan pembiayaan perlindungan lahan pertanian pangan berkelanjutan menurut Bappeda Kabupaten Kendal belum dicantumkan dalam Anggaran Pendapatan dan Belanja Daerah karena belum jelasnya penetapan lahan pertanian pangan berkelanjutan.

Peran Serta Masyarakat. Peran serta masyarakat di Kecamatan Kaliwungu, khususnya Desa Sumberejo, Desa Karangtengah, Desa Sarirejo, Desa Krajan Kulon, Desa Mororejo, Desa Kutoharjo dan Desa Nolokerto yang terdapat penetapan lahan pertanian pangan berkelanjutan pada umumnya tidak mengetahui dan bingung akan adanya penetapan lahan pertanian pangan berkelanjutan sehingga peran serta masyarakat belum terlihat.

Pengawasan. Pelaksanaan pengawasan berupa laporan belum pernah dilaksanakan di Kecamatan Kaliwungu berdasarkan keterangan para perangkat desa yang ditetapkan lahan pertanian pangan berkelanjutan (Desa Sumberejo, Desa Karangtengah, Desa Sarirejo, Desa Krajan Kulon, Desa Mororejo, Desa Kutoharjo dan Desa Nolokerto), sehingga kegiatan pemantauan dan evaluasi juga belum dilaksanakan di Kecamatan Kaliwungu.

\section{SIMPULAN}

Pada Kecamatan Kaliwungu, Kabupaten Kendal dari tahun 2011 sampai dengan tahun 2017 telah terjadi perubahan penggunaan tanah dari tanah pertanian (sawah 2x padi/tahun, dan tegalan), tambak dan tanah terbuka sementara menjadi non pertanian (perumahan, kampung, tambak, tanah terbuka sementara dan industri) seluas 166,06 ha; Secara keseluruhan, perencanaan dan penetapan lahan pertanian pangan berkelanjutan baik dalam Perda RTRW maupun Perda LP2B dilaksanakan sepihak oleh pemerintah, tidak didasarkan pada pendapat atau usulan dari masyarakat serta kurangnya koordinasi antar pemerintah sendiri dalam penetapan LP2B; Indikator pengembangan, pemanfaatan, pembinaan, sampai dengan pengawasan belum diterapkan karena semua wilayah masih terfokus pada proses perencanaan dan penetapan lp2b.

\section{DAFTAR PUSTAKA}

Mahardika, B.P. dan L. M. (2018). Dampak Alih Fungsi Lahan Pertanian Menjadi Lahan Terbangun untuk Industri terhadap Kondisi Sosial Ekonomi Masyarakat Sebagian Wilayah Kecamatan Ceper. Jurnal Bumi Indonesia, 7. https://doi.org/10.1017/CB097811074153 24.004

Dewi, N. K., \& Rudiarto, I. (2013). Identifikasi Alih Fungsi Lahan Pertanian dan Kondisi Sosial Ekonomi Masyarakat Daerah Pinggiran di Kecamatan Gunungpati Kota Semarang. Jurnal Wilayah Dan Lingkungan, 1(2), 175. https://doi.org/10.14710/jwl.1.2.175-188

Junti, G.I., E. M. dan Su. (2016). Perlindungan Lahan Pertanian Pangan Berkelanjutan Guna Memperkokoh Ketahanan Pangan Wilayah (Studi di Kabupaten Bantul, Daerah Istimewa Yogyakarta). Jurnal Ketahanan Nasional, 22(1), https://doi.org/10.22146/jkn.16666

I Ketut, S. (2014). Dampak Alih Fungsi Lahan Pertanian Terhadap Ketahanan Pangan. Media Komunikasi Geografi, 53(9), 16891699. 
https://doi.org/10.1017/CB097811074153 24.004

Kaputra, I. (2013). Alih Fungsi Lahan, Pembangunan Pertanian \& Ketahanan Pangan. Jurnal Strukturasi, 1(Juli), 25-39.

Kusumastuti, A. C., M. Kolopaking, L., \& Barus, B. (2018). Factors Affecting the Converstion of Agricultural Land in Pandeglang Regency. Sodality: Jurnal Sosiologi Pedesaan, 6(2). https://doi.org/10.22500/sodality.v6i2.232 34

Kusumawardhani, A. D., Syetiawan, A., Rah, Y., \& Ristiantri, A. (2020). Estimasi Lahan Sawah Bukaan Baru Di Pulau Jawa Estimated New Cultivated Land in Java Island.

Mustapa, L. A., Purnamadewi, Y. L., \& Dharmawan, A. H. (2019). Dampak dan Keberlanjutan Program Cetak Sawah di Kabupaten Katingan, Provinsi Kalimantan Tengah. Analisis Kebijakan Pertanian, 17(2), 123. https://doi.org/10.21082/akp.v17n2.2019.1 23-137

Natalia, B. (2014). Implementasi Program Zona Air Minum Prima (ZAMP) Untuk Memenuhi Kebutuhan Air Minum Masyarakat (Studi Pada PDAM Kota Malang). Jurnal Administrasi Publik Mahasiswa Universitas Brawijaya, 2(1), 11-15.

Nurpita, A., Wihastuti, L., \& Andjani, I. Y. (2018). Dampak Alih Fungsi Lahan Sawah terhadap Ketahanan Pangan Beras. Jurnal Gama Societa, 1(1), 103-110. https://doi.org/10.1007/s00221-013-3713$\mathrm{z}$

P, C. T. B. J., Purwanto, J., Fajarningsih, R. U., \& Ani, S. W. (2010). Dampak Alih Fungsi Lahan Pertanian Ke Sektor Non Pertanian Terhadap Ketersediaan Beras Di Kabupaten Klaten
Provinsi Jawa Tengah. Caraka Tani: Journal of Sustainable Agriculture, 25(1), 38. https://doi.org/10.20961/carakatani.v25i1. 15732.

Peraturan Daerah Provinsi Jawa Tengah Nomor 2 Tahun 2013 tentang Perlindungan Lahan Pertanian Pangan Berkelanjutan Pangan Berkelanjutan Provinsi Jawa Tengah

Peraturan Daerah Kabupaten Kendal Nomor 13 Tahun 2013 tentang Perlindungan Lahan Pertanian Pangan Berkelanjutan di Kabupaten KendalRosyadi, I. dan D. P. (2012). Tingkat Ketahanan Pangan Rumah Tangga Di Desa Tertinggal. Jurnal Ekonomi Pembangunan, 13(2).

Prasada, I. M. Y., \& Rosa, T. A. (2018). Dampak Alih Fungsi Lahan Sawah Terhadap Ketahanan Pangan Di Daerah Istimewa Yogyakarta. Jurnal Sosial Ekonomi Pertanian, 14(3), 210. https://doi.org/10.20956/jsep.v14i3.4805

Purwaningsih, Y., Istiqomah, N., \& Sutomo, S. (2015). Analisis Dampak Alih Fungsi Lahan terhadap Tingkat Ketahanan Pangan Rumah Tangga Petani di Kabupaten Karanganyar Provinsi Jawa Tengah. AGRARIS: Journal of Agribusiness and Rural Development Research, 1(2), 98-107. https://doi.org/10.18196/agr.1213

Putra, R. N. (2015). Implementasi Kebijakan Pengendalian Alih Fungsi Lahan Pertanian Di Kota Batu Sebagai Kawasan Agropolitan. Kebijakan Dan Manajemen Publik Volume, 3(2), 71-80.

Undang Undang Nomor 41 Tahun 2009 tentang Perlindungan Lahan Pertanian Pangan Berkelanjutan

Undang-Undang No 26 Tahun 2007 tentang Penataan Ruang. 